\title{
Mycoplasma hominis in pregnancy
}

\author{
D. M. JONES \\ From the Department of Pathology, Withington Hospital, Manchester
}

SYNOPSIS One hundred and seventyone antenatal patients were examined for the presence of 'large colony' mycoplasmas in the vagina, and for complement-fixing antibody to Mycoplasma hominis. In 25 patients the findings before and after delivery were compared. In patients from whom $M$. hominis was grown, antibody was twice as common after delivery, and the development of antibody was sometimes associated with pyrexia and signs of genital tract infection.

Mycoplasma hominis is a common inhabitant of the female genital tract. Although usually a commensal there is evidence that this organism may cause genital tract and puerperal infections accompanied by the appearance of circulating antibody (Stokes, 1955; Lemcke and Csonka, 1962). The incidence of antibody to $M$. hominis in the general female population has been shown to increase with age through the reproductive years (Jones and Sequeira, 1966). It is therefore of interest to establish if there is an antibody response to this organism during pregnancy and the puerperium and under what clinical conditions this occurs.

\section{MATERIALS AND METHODS}

PATIENTS Swabs were taken from the vaginal vault of 171 consecutive patients seen in the antenatal booking clinic, and examined for the presence of Mycoplasma species. Samples of serum were also taken and examined for complement-fixing antibody to Mycomplasa hominis. From 25 of these patients further samples of serum and vaginal swabs were taken at a subsequent visit to the antenatal clinic, usually about the 30th week of gestation. Vaginal swabs were collected when the patients were admitted for delivery and both swabs and serum collected in the postnatal clinic six weeks after delivery.

CULTURAL TECHNIQUE Vaginal swabs were plated on to P.P.L.O. agar (Difco) containing 20\% unheated human serum, 1/2000 thalium acetate, and 1,000 units of penicillin per $\mathrm{ml}$. The plates were incubated in a moist atmosphere at $34^{\circ} \mathrm{C}$. for three days before being examined for the presence of mycoplasma colonies. Strains of Mycoplasma sp. that were isolated were all shown to be Mycoplasma hominis using the growth inhibition technique of Clyde (1964).

Received for publication 17 March 1967.
SEROLOGICAL TESTS The complement-fixation antigen was prepared by the method of Card (1959). The method of performing the complement-fixation test has been described elsewhere (Jones and Sequeira, 1966). At least one antenatal serum sample from each patient was tested at the same time as the postnatal sample.

\section{RESULTS}

Mycoplasma hominis was cultured from the vaginal swabs of 43 out of 171 antenatal patients $(24.5 \%)$. Complement-fixing antibody was present in 27 $(15 \%)$ and in 14 patients both antibody and $M$. hominis were present.

Twenty-five patients selected entirely at random were followed up during pregnancy and in the postnatal clinic. Of the patients studied in this way 13 had mycoplasmas in the vagina when examined in the antenatal clinic, the remaining 12 did not. Considered as two groups, the results obtained are shown in Tables I and II.

The serology and cultural results obtained at the booking clinic attendance did not differ significantly from the results obtained at about the 30th week of pregnancy.

The case notes of these 25 patients were reviewed with particular reference to the occurence of pyrexia and trichomonas infection. The history of patient 13 is of sufficient interest to report in more detail.

This patient was aged 21 , primigravid and unmarried, and she attended the antenatal clinic for the first time when 37 weeks pregnant. At this time $M$. hominis was grown from the vagina but no antibodies were present. Three weeks later she was admitted in labour and her temperature rose soon after admission. She was delivered by caesarian section in view of failure to progress in labour, and the presence of intrauterine infection. A swab taken from the uterine cavity at operation yielded 
TABLE I

\begin{tabular}{|c|c|c|c|c|c|c|c|c|c|c|c|}
\hline Patient & Age & $\begin{array}{l}\text { Previous } \\
\text { Pregnancies }\end{array}$ & Abortions & $\begin{array}{l}\text { Antenatal } \\
\text { Culture }\end{array}$ & C.F.T. & $\begin{array}{l}\text { In-patient } \\
\text { Culture }\end{array}$ & $\begin{array}{l}\text { Postnatal } \\
\text { Culture }\end{array}$ & C.F.T. & Pyrexia & Remarks & $\begin{array}{l}\text { Duration of } \\
\text { Hospital Stay } \\
\text { (days) }\end{array}$ \\
\hline 1 & 30 & 4 & - & - & $<5$ & - & - & $<5$ & - & - & 5 \\
\hline 2 & 21 & 0 & - & - & $<5$ & + & nt & $<5$ & - & $\begin{array}{l}\text { Abortion } \\
\text { at } 4 / 12 \\
\text { gestation }\end{array}$ & 2 \\
\hline 3 & 30 & 1 & - & - & $<5$ & + & + & 5 & + & - & 6 \\
\hline 4 & 23 & 1 & 2 & - & 20 & - & - & 10 & - & - & 3 \\
\hline 5 & 26 & 1 & 2 & - & 80 & - & - & 10 & - & - & 4 \\
\hline 6 & 20 & 0 & 1 & - & $<5$ & - & - & $<5$ & + & $3^{\circ}$ tear & 9 \\
\hline 7 & 32 & 1 & - & - & $<5$ & - & - & $<5$ & - & - & 3 \\
\hline 8 & 32 & 0 & - & - & $<5$ & - & - & $<5$ & - & - & 7 \\
\hline 9 & 25 & 1 & - & - & $<5$ & - & - & $<5$ & - & - & 8 \\
\hline 10 & 22 & 0 & 1 & - & $<5$ & - & - & $<5$ & - & - & 4 \\
\hline 11 & 26 & 2 & - & - & $<5$ & - & - & $<5$ & - & - & 3 \\
\hline 12 & 21 & 0 & - & - & $<5$ & - & - & $<5$ & - & - & 6 \\
\hline
\end{tabular}

TABLE II

\begin{tabular}{|c|c|c|c|c|c|c|c|c|c|c|c|}
\hline Patient & Age & $\begin{array}{l}\text { Previous } \\
\text { Pregnancies }\end{array}$ & Abortions & $\begin{array}{l}\text { Antenatal } \\
\text { Culture }\end{array}$ & C.F.T. & $\begin{array}{l}\text { In-patient } \\
\text { Culture }\end{array}$ & $\begin{array}{l}\text { Post-natal } \\
\text { Culture }\end{array}$ & C.F.T. & Pyrexia & 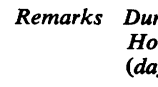 & $\begin{array}{l}\text { tion of } \\
\text { ital Stay } \\
\text { ) }\end{array}$ \\
\hline 13 & 21 & 0 & - & + & $<5$ & + & + & 20 & + & $\begin{array}{l}\text { Intra- } \\
\text { uterine } \\
\text { Infection }\end{array}$ & 17 \\
\hline 14 & 18 & 0 & - & + & 5 & nt & - & 10 & - & - & 4 \\
\hline 15 & 26 & 0 & - & + & $<5$ & - & + & 20 & + & - & 9 \\
\hline 16 & 27 & 3 & - & + & 20 & - & - & 10 & - & - & 4 \\
\hline 17 & 24 & 1 & - & + & $<5$ & + & - & 5 & + & - & 6 \\
\hline 18 & 26 & 4 & 1 & + & 40 & + & + & 40 & - & $\begin{array}{l}\text { Trichomonas } \\
\text { infection }\end{array}$ & 10 \\
\hline 19 & 32 & 3 & - & + & $<5$ & - & + & 20 & - & $\begin{array}{l}\text { Trichomonas } \\
\text { infection }\end{array}$ & 8 \\
\hline 20 & 21 & 0 & - & + & $<5$ & + & + & 80 & - & - & 6 \\
\hline 21 & 39 & 2 & 2 & + & $<5$ & - & - & $<5$ & + & - & 20 \\
\hline 22 & 41 & 9 & - & + & 80 & + & + & 20 & - & $\begin{array}{l}\text { Trichomonas } \\
\text { infection }\end{array}$ & 25 \\
\hline 23 & 19 & 0 & - & + & $<5$ & - & - & $<5$ & + & - & 7 \\
\hline 24 & 30 & 0 & - & + & $<5$ & - & + & 20 & + & - & 7 \\
\hline 25 & 18 & 0 & - & + & 80 & - & + & 5 & - & - & 3 \\
\hline
\end{tabular}

a pure growth of $M$. hominis. The patient was transfused and treated with ampicillin and her temperature remained elevated for four days. The baby was normal and healthy and was given prophylactic antibiotic treatment. Blood taken eight days after the onset of pyrexia had a complement-fixing antibody titre of $1 / 20$ to $M$. hominis.

\section{DISCUSSION}

The rate of isolation of $M$. hominis from these antenatal patients is in general agreement with that in other series (Nicol and Edward, 1953). The frequency of antibody in this group is the same as in a much larger series of antenatal patients attending several hospitals (Jones and Sequeira, 1966).

In the 25 patients followed up after delivery, 11 had no antibody when seen at the booking clinic or six weeks after delivery; from nine of these patients $M$. hominis was not isolated. In four patients there was no significant change in antibody level over the several months of observation whereas in three patients a fourfold or greater fall in titre was observed. These results indicate that complement-fixing antibody persists in the circulation for 9 many months. Whether this antibody is derived from a single infective episode or from repeated antigenic stimuli from the continued presence of the organism is conjectural.

In seven patients antibody was present in the $N$ postnatal serum sample whereas previous samples $\mathbb{N}$ had been negative. In five of these cases the patient $\mathscr{O}$ was febrile after delivery. It is not possible to con- $c$ clude that in all of these cases the pyrexia was due $\overparen{\Phi}$ solely to $M$. hominis but at least this organism may $\stackrel{\mathscr{C}}{?}$ have had a contributary role. In one patient (no. 13) in whom $M$. hominis was grown from the endometrium and antibody appeared there is good evidence for the pathogenic role of the mycoplasma.

These patients may be divided into groups on the basis of the presence of $M$. hominis in the vagina 
when seen in the antenatal clinic. In the 'negative culture' group two patients had positive cultures when admitted to hospital, in one there was puerperal pyrexia and development of a low titre of antibody, in the other a spontaneous abortion occurred. In this latter case the foetal tissues were available for culture but $M$. hominis was not grown, and there was no maternal antibody response. Occasionally abortion is accompanied by maternal 'antibody response to $M$. hominis and the foetus also may become infected (Jones, 1967).

In the second 'culture-positive' group, there were more cases of pueperal pyrexia, and the average length of stay in hospital was longer in this group. The average age in the two groups is the same, and there is no obvious difference in previous obstetric history. Four patients were unmarried and these were all in the second group. Trichomonas infection was present in three patients in the second group and there is a known association between trichomonas and mycoplasma (Gordon, Hughes, and Barr, 1966).

From the results obtained with this small un- selected series of pregnant women, it appears that $M$. hominis may often play some part in puerperal infections, but presumably it is not always the principal infecting organism. In the patients studied the frequency of antibody to $M$. hominis was doubled after delivery.

Pregnancy is therefore an important factor in explaining the distribution of antibody in the female population.

I am indebted to Dr. R. W. Burslem and Mr. J. B. Jones for permission to study the patients under their care, and to Mr. A. E. Eldridge for technical assistance. This work was supported by a grant from the Research SubCommittee of the Manchester Regional Hospital Board.

\section{REFERENCES}

Card, D. H. (1959). Brit. J. vener. Dis., 35, 27.

Clyde, W. A., Jr. (1964). J. Immunol., 92, 958.

Gordon, A. M., Hughes, H. E., and Barr, G. T. D. (1966). J. clin Path. $19,429$.

Jones, D. M., and Sequeira, P. J. L. (1966). J. Hyg. (Lond.), 64, 441. (1967). Brit. med. J., 1, 338.

Lemcke, R., and Csonka, G. W. (1962). Brit. J. vener Dis., 38, 212.

Nicol, C. S., and Edward, D. G. (1953). Ibid., 29, 141.

Stokes, E. J. (1955). Lancet, 1, 276. 